\title{
The Use of Prezi with Know, Want, and Learn (KWL) Strategy to Enhance Students Reading Comprehension
}

\author{
Sitti Maryam Hamid \\ sittimaryamhamid@ymail.com \\ Qashas Rahman \\ qashas54@gmail.com \\ Haryanto Atmowardoyo \\ aharyanto_fbsunm@yahoo.co.id \\ State University of Makassar, Indonesia
}

\begin{abstract}
The objectives of this research were to find out whether the use of Prezi with KWL Strategy enhances the reading comprehension and the students' interest. This research employed quasi-experimental design. The population of this research was the first-grade students of SMAN 5 Makassar in academic 2015/2016. This research employed cluster random sampling technique. The sample consisted of 72 students which belong to two classes; 36 students in experimental class and also 36 students in control class. Research instruments were used to collect the data in this research namely reading comprehension test and questionnaire. The result of the students' reading score in this research showed that the experimental class improved significantly from 69.69 up to 86.61 . While in control class the result improved from 66.22 up to 75.89 . Therefore, the significant values of Independent t-test $0.000<\alpha=0.05$. It means that the alternative hypothesis $\left(\mathrm{H}_{1}\right)$ was accepted. Moreover, based on the students' response on questionnaire showed that the mean score of interest was 80.61 and it was categorized as interested.
\end{abstract}

Keywords: KWL Strategy, Prezi, reading comprehension, interest

\section{INTRODUCTION}

Reading is a medium of knowing or understanding text that needs particular attention and concentration. It is one of the specific abilities which helps people understands and catch the message of the text. William (1984) stated that reading is a process whereby one looks at and understands what has been read. Moreover, reading is eye working processes that information transfers into the brain for produce the information. Harmer (1985) states that reading as an exercise dominated by the eyes and the brain". Furthermore, reading is an essential skill that supports students in teaching and learning process, national examination, even in proficiencies test (TOEFL and IELTS). 
Hamid, Rahman, Atmowardoyo: The Use of Prezi with Know ...

Pintrich et.al. (1999) state that reading is a crucial skill for professional successful and academic learning. In some academic subject areas, school success is dependent on knowing how to read, understand what has been read, and apply the content to future learning.

Some difficulties and problems faced by the teachers in their reading have appeared for a long time. Many students sometimes get bored and cannot continue reading the text in the textbook. Generally, the problems faced by the students are caused by some reason; the students are not able to answer the question because they did not comprehend the content of the text and they did not have many vocabularies to understand the text and were not interested in reading.

Dealing with the difficulty in reading comprehension, the first-grade students of SMAN 5 Makassar shown by the low reading comprehension. It is still less than the standard of Minimum Completeness Criterion or Kriteria Ketuntasan Minimal (KKM) of English subject of SMAN 5 Makassar that is 76. In other words, the English score that the students gain is 70 at average. Thus, it still needs to be enhanced in order to reach 76 or higher than it.

Referring to the obstacles above, the researcher implemented one interesting strategy and media in teaching. In this research, the researcher focused on narrative text. Know, Want, and Learn (KWL) is a good strategy that can be used to teach reading. According to Ogle (1986), KWL strategy helps children become good readers by getting them to do many of the things that good readers do. This strategy gets children to read silently with comprehension. In addition, children relate new information to what they already know when they confirm or disconfirm the information in the $K$ column. Further, the children learn to set their own purposes for reading when they generate questions for the $W$ column. Their reading to answer these questions helps them concentrate while they are reading as they more actively monitor their own comprehension. The L column affords students the opportunity to summarize what they read. When they put the information in their own words, they better understand what they know and what they do not know. This helps them move into a possible next step which involves having them generate more questions and use a variety of resources to learn more information. Finally, taking this strategy into a publication step helps them organize the information and write it for presentation to others. This strengthens their learning of the information, involves them in doing what good readers do, and teaches them about their own reading processes. 
18| ELT Worldwide Vol. 3 No. 1 April 2016

In addition, Prezi is one of the useful media in teaching and learning. It is software manufacturing slide presentations online. In contrast, PowerPoint, Prezi provides more free space to create an idea in the manufacture of a slide presentation. One of the advantages of Prezi is the zoomable canvas so that the presenter can focus slide into every sentence with the slide movement is quite dynamic and varied. Interesting learning media will make students more stimulated to pay attention to the material presented; therefore, the purpose of the material would be more easily understood.

Consequently, in this research the researcher applied Prezi with KWL Strategy to enhance the students' reading comprehension at the first grade of SMAN 5 Makassar. Hopefully, this media and strategy can give a positive impact on students; interest in studying English as well as in improving reading comprehension. In addition, the purpose of this research as to find out whether the use of Prezi with KWL Strategy enhances the reading comprehension and the students' interest in studying English reading.

\section{LITERATURE REVIEW}

\section{Previous Related Findings}

According to Riswanto et. al. (2014), Know, Want, Learned (KWL) strategy is effective to use improving students' reading comprehension showed that the effectiveness was indicated by the result of the StepWise regression formula that the contribution of KWL strategy on students' reading comprehension achievement was significantly improved.

Setiawan et.al. (2013) found that teaching reading comprehension of descriptive text through KWL strategy has been proven effective. Hawa (2013) conducted a study "The Effect of Using Know Want Learn (KWL) Plus Strategy toward Reading Comprehension on Exposition Text". She concluded that the students were taught by using KWL Plus strategy toward reading comprehension had a better score than students were not using it.

Manning et. al. (2011) found that students can use Twitter and Schoology, to communicate in new ways, or they can use Prezi to present information in completely different format. In addition, using innovative tools students and teacher can work together to re-envision new school will function for a century to come. Hamra et.al (2010) indicates that most of Indonesia students still find it difficult to comprehend English textbooks. 
The difficulty comes from different aspects, among others; ineffective reading habits, the negative reading attitude, the lack of reading interest, reading knowledge or language knowledge, reading skill, reading strategies, reading participation.

\section{Some Pertinent Ideas}

\section{Reading}

Zare, et.al (2013) comment that reading is a cognitive activity in which the reader takes part in a conversation with the author through the text. In addition, Rivers (1987:674) states that reading comprehension entails more than knowledge of vocabulary and syntax. It also requires an ability to perceive the exact nature of being communicated.

\section{Know, Want, and Learn (KWL) Strategy}

Jared et.al (1997) states that the KWL strategy is strategies that create students' to enhance reading comprehension in content areas. Moreover, Ogle (1986) states that KWL is an instructional reading strategy that is used to guide students through a text. The students begin by brainstorming everything they Know about a topic. This information is recorded in the $K$ column of a KWL chart. Students then generate a list of questions about what they Want to Know about the topic. These questions are listed in the $W$ column of the chart. During or after reading, students answer the questions that are in the $W$ column. This new information that they have Learned is recorded in the $L$ column of the KWL chart.

\section{Prezi}

Manning et.al (2011) states that Prezi is an interactive and visually pleasing uses zooming and spatial relationships to present information. Furthermore, Strasser (2014) states that Prezi is a cloudbased presentation editor that allows the user to create a presentation that zoom.

\section{Interest}

Interest is desire or curiosity to know deeply about something that reflects from attitude, attention, even perception. According to Good (1959), interest is a subject-object attitude, concerned with a condition involving a perception or idea in attention and a combination of intellectual and feeling curiosity condition by experience. Interest also refers to the kinds of thing we appreciate and enjoy. 
20| ELT Worldwide Vol. 3 No. 1 April 2016

\section{METHOD}

\section{Design and Samples}

This research applied quasi-experimental design by using two groups namely; an experimental and a control group. The researcher used cluster random sampling technique which means two classes from the fifteen classes takes as the sample $\mathrm{X}_{1}$ until $\mathrm{X}_{15}$. $\mathrm{X}_{2}$ was taken as the experimental group and $\mathrm{X}_{4}$ was taken as control group. The result of calculation of the total number sample was 72 students. The experimental group employed treatment by using Prezi with KWL Strategy while the control group was employed treatment by using three phase technique where the students were asked to read narrative text based on the topic given by the teacher. Both of groups were given pretest and posttest.

\section{Instruments and Procedures}

This research used two kinds of instruments in collecting data namely reading test and questionnaire. In reading test, the students were given a narrative reading test means that the researcher provided multiple choices. It administered in pre-test and post-test. The pre-test was used to measure of the prior knowledge of the students while the post-test was aimed to see the students' reading comprehension after giving the treatment to enhance reading comprehension. Meanwhile, a questionnaire was distributed to students in the experimental group to measure their interest in learning reading narrative text through Prezi with KWL Strategy.

The treatment in experimental and control groups were conducted for six meeting based on the general steps below:

\section{Experimental Group}

1. The researcher explained the objectives and the procedures of teaching and learning process to the students. It aimed to set a purpose for reading.

2. The researcher showed a text in Prezi Presentation and gave instruction.

3. One of the students in each group must be logged in their Prezi

4. After logging in, the students created KWL charts

5. Each group read the title and concern on the content of the text. It helped students to monitor their comprehension. 
Hamid, Rahman, Atmowardoyo: The Use of Prezi with Know ... $\mid 21$

6. The researcher asked students to brainstorm words, terms, or phrases they associated with a topic and filled out the K column in their Prezi.

7. The researcher asked students what they wanted to learn about the topic and filled out on the $\mathrm{W}$ column in their Prezi.

8. The researcher had students to read the text and fill out the $\mathrm{L}$ column of their charts in their Prezi.

9. Students discussed the information that students recorded in the L column.

10. The researcher encouraged students to search any questions in the $\mathrm{W}$ column that were not answered by the text. It provided an opportunity for students to expand ideas beyond the text.

11. The researcher checked the Prezi Presentation from each group. It allowed students assessing their comprehension of the text.

\section{Control Group}

1) The researcher explained the objectives of the teaching and learning process to the students.

2) The researcher introduced the topic of the reading text.

3) The researcher asked the students to read the text.

4) The researcher asked the students to find the difficult words and find their meaning by using a dictionary.

5) The researcher asked the students to answer the questions of the text.

6) The researcher monitored the students' activities.

7) The researcher checked the students' answer.

8) The researcher closed the class with giving an assignment for homework.

\section{Data Analysis}

The data analyzed through quantitative analysis. To get the score, the researcher used the conversion of students' score in reading comprehension. Calculating the mean score and standard deviation of the students' achievement by using SPSS 20.0. The data of questionnaire was analyzed by using Likert Scale. it aimed to see the students' interest about the use of Prezi with KWL Strategy in enhancing reading comprehension.

In reading test, the data were analyzed by employing the following procedures: 
22| ELT Worldwide Vol. 3 No. 1 April 2016

\section{Reading comprehension test}

a. Scoring the students' answers of pretest and posttest. Each of students' correct answer will get 1 and the wrong answer will get 0 . The formula for indicating the students' score as follows:

Score $=\frac{\text { Obtained scores }}{\text { Maximum scores }}$ X 100 (interval of the score level)

(Depdiknas, 2006)

Table 1. The Conversion of Students' Score in Reading Comprehension

\begin{tabular}{|c|c|c|}
\hline No & $\begin{array}{c}\text { The Number of the Students' } \\
\text { correct answer }\end{array}$ & Score \\
\hline 1 & 30 & 100 \\
\hline 2 & 29 & 97 \\
\hline 3 & 28 & 93 \\
\hline 4 & 27 & 90 \\
\hline 5 & 26 & 87 \\
\hline 6 & 25 & 83 \\
\hline 7 & 24 & 80 \\
\hline 8 & 23 & 77 \\
\hline 9 & 22 & 73 \\
\hline 10 & 21 & 70 \\
\hline 11 & 20 & 67 \\
\hline 12 & 19 & 63 \\
\hline 13 & 18 & 60 \\
\hline 14 & 17 & 57 \\
\hline 15 & 16 & 53 \\
\hline 16 & 15 & 50 \\
\hline 17 & 14 & 47 \\
\hline 18 & 13 & 43 \\
\hline 19 & 12 & 40 \\
\hline 20 & 11 & 37 \\
\hline 21 & 10 & 33 \\
\hline 22 & 9 & 30 \\
\hline 23 & 8 & 27 \\
\hline 24 & 7 & 23 \\
\hline 25 & 6 & 20 \\
\hline 26 & 5 & 17 \\
\hline 27 & 4 & 13 \\
\hline 28 & 3 & 10 \\
\hline 29 & 2 & 7 \\
\hline 30 & 1 & 3 \\
\hline
\end{tabular}


Hamid, Rahman, Atmowardoyo: The Use of Prezi with Know ... 23

b. Classifying the scores of the students' answer. The scores were classified into seven level classifications which adapted to the scoring system from Depdiknas (2006:38) as follows:

Table 2. Scoring Classification of Students' Reading Achievement

\begin{tabular}{|c|c|c|}
\hline No & Interval Score & Classification \\
\hline 1 & $96-100$ & Excellent \\
2 & $86-95$ & Very Good \\
3 & $76-85$ & Good \\
4 & $66-75$ & Fairly Good \\
5 & $56-65$ & Fair \\
6 & $36-55$ & Poor \\
7 & $0-35$ & Very Poor \\
\hline
\end{tabular}

(Depdiknas, 2006)

c. Calculating the mean score of the students' answer. To find out the mean score, standard deviation and the t-test value between the pre-test and the post-test of both experimental and control group by using Statistical Package for Social Sciences (SPSS) program version 20.0 (Gay et al, 2006:378).

The data of questionnaire was analyzed by using Likert Scale. it aimed to see the students' interest about the use of Prezi with KWL Strategy in enhancing reading comprehension. The measuring of instrument item of Likert Scale consisted of positive and negative statements as follows:

\section{Scoring Data}

The questionnaire was given to the students by using Likert scale. It aimed at asking the sample to respond to a series of statements by indicating whether one strongly agrees (SA), agrees (A), undecided (U), disagrees (D), or strongly disagrees (SD) with the statements given. Each response had its own value. Look at the table below: 
24| ELT Worldwide Vol. 3 No. 1 April 2016

Table 3. Likert Scale

\begin{tabular}{|c|c|c|}
\hline $\begin{array}{c}\text { Positive statement } \\
\text { Score }\end{array}$ & Category & $\begin{array}{c}\text { Negative } \\
\text { statement score }\end{array}$ \\
\hline 5 & Strongly Agree & 1 \\
4 & Agree & 2 \\
3 & Undecided & 3 \\
2 & Disagree & 4 \\
1 & Strongly & 5 \\
& Disagree \\
\hline
\end{tabular}

2. Measuring the students' interest

As explained by the researcher previously, the questionnaire consisted of 20 items. It concern on four items namely: students' involvement, a feeling of pleasure, attraction, and attention. Therefore, the students' interest can be classified as follow:

Table 4. Scoring Classification of The Students' Interest

\begin{tabular}{|c|c|c|}
\hline No. & Interval score & Classification \\
\hline 1 & $85-100$ & Very high \\
2 & $69-84$ & High \\
3 & $52-68$ & Moderate \\
4 & $36-51$ & Low \\
5 & $20-35$ & Very low \\
\hline \multicolumn{2}{|c}{ (Sugiyono, 2008:137) } \\
\hline \multicolumn{2}{|c}{}
\end{tabular}

\section{RESULTS AND DISCUSSIONS}

Regarding the findings explained previously, it shows that the reading comprehension of the first-grade students of SMAN 5 Makassar improved in the experimental group. It supported by the students' frequency and rate percentage of the students' pretest and posttest result. the students score in the experimental group by using Prezi with KWL Strategy in teaching reading was better than before treatment.

Referring to the students' reading pretest of both of experimental and control groups, the result of findings shows that the most of the students are still lack of skill in reading a narrative text. 
Hamid, Rahman, Atmowardoyo: The Use of Prezi with Know ... $\mid 25$

\section{Students' Reading Comprehension}

a. The Students Reading Comprehension in Pre-test and Post-test of Experimental and Control Group

The distribution of the score of the students' reading comprehension from experimental and control groups in the post-test shows a difference from the pretest. After treatment, both groups showed improvement, but in the experimental group, the improvement was higher than that of the control group. The rating percentage of pretest and posttest are shown in the table below:

Table 5. The Rate Percentage of Pretest and Posttest.

\begin{tabular}{|c|c|c|c|c|c|c|c|c|c|}
\hline Classification & Score & \multicolumn{3}{|c|}{ Experimental Group } & \multicolumn{4}{|c|}{ Control Group } \\
\cline { 3 - 10 } & & Pretest & \multicolumn{2}{|c|}{ Post-test } & \multicolumn{2}{|c|}{ Pretest } & \multicolumn{2}{c|}{ Post-test } \\
\cline { 3 - 10 } & & $\mathrm{F}$ & $\begin{array}{c}\mathrm{P} \\
(\%)\end{array}$ & $\mathrm{F}$ & $\begin{array}{c}\mathrm{P} \\
(\%)\end{array}$ & $\mathrm{F}$ & $\begin{array}{c}\mathrm{P} \\
(\%)\end{array}$ & $\mathrm{F}$ & $\begin{array}{c}\mathrm{P} \\
(\%)\end{array}$ \\
\hline Excellent & $96-100$ & 0 & 0 & 0 & 0 & 0 & 0 & 0 & 0 \\
\hline Very Good & $86-95$ & 0 & 0 & 19 & 53 & 0 & 0 & 1 & 3 \\
\hline Good & $78-85$ & 12 & 33 & 17 & 47 & 4 & 11 & 18 & 50 \\
\hline Fairly Good & $66-75$ & 15 & 42 & 0 & 0 & 15 & 42 & 16 & 44 \\
\hline Fair & $56-65$ & 7 & 19 & 0 & 0 & 13 & 36 & 1 & 3 \\
\hline Poor & $36-55$ & 2 & 6 & 0 & 0 & 4 & 11 & 0 & 0 \\
\hline Very Poor & $0-36$ & 0 & 0 & 0 & 0 & 0 & 0 & 0 & 0 \\
\hline Total & & 36 & 100 & 36 & 100 & 36 & 100 & 36 & 100 \\
\hline
\end{tabular}

Based on the data above, the difference frequency in experimental group and control group in pretest and posttest. It is proven by the rate percentage in the experimental group in posttest $19(53 \%)$ students were classified as very good as classification while, in control class 1 (3\%) student was classified as very good as classification. It assumes that the students percentage improve significantly after treatment by using Prezi with KWL Strategy in the experimental group than three phase technique in the control group. 
26| ELT Worldwide Vol. 3 No. 1 April 2016

Table 6. The Mean Score and Standard Deviation of Students'

Reading Comprehension in Pre-test and Post-test

\begin{tabular}{|c|c|c|c|c|c|}
\hline NO & GROUP & \multicolumn{2}{|c|}{ Mean Score } & \multicolumn{2}{|c|}{$\begin{array}{c}\text { Standard } \\
\text { Deviation }\end{array}$} \\
\cline { 3 - 6 } & & \multicolumn{2}{|c|}{} & \multicolumn{2}{c|}{} \\
\cline { 3 - 6 } & & Pretest & Posttest & Pretest & Posttest \\
\hline 1 & Experimental & 69.69 & 86.61 & 8.655 & 5.228 \\
\hline 2 & Control & 66.22 & 75.89 & 7.491 & 6.480 \\
& & & & & \\
\hline
\end{tabular}

Table 6 shows that the mean score of pre-test in the experimental group is higher than the control group, (69.69>66.22). 66.69 and 66.22 are classified as fairly good classification. This means that the students of the experimental and control groups are the same category of the treatment. Meanwhile, the mean score of post-test in the experimental group is higher than the mean score of the control group, (86.61>75.89). 86.61 is classified as the very good category. While, 75.89 is classified as the fairly good category. This means that Prezi with KWL Strategy which was applied in the experimental group is more successful to enhance the students' reading comprehension than three phase technique which was applied in the control group.

b. Test of significance (T-test)

The hypotheses were tested by using inferential statistics. In this case, the researcher used t-test (testing of significance) for an independent sample test. It was intended to know the significance difference between the result of the students' mean score in pretest and posttest in experimental group and control group. The result of t-test was calculated by using SPSS version 20.0. After using the statistics, the researcher found the probability value of t-test as presented in the following table 7 
Hamid, Rahman, Atmowardoyo: The Use of Prezi with Know ... $\mid 27$

Table 7 The Probability Value of T-test of the Students' Reading Comprehension Improvement in Experimental and the Control Group

Independent Samples Test

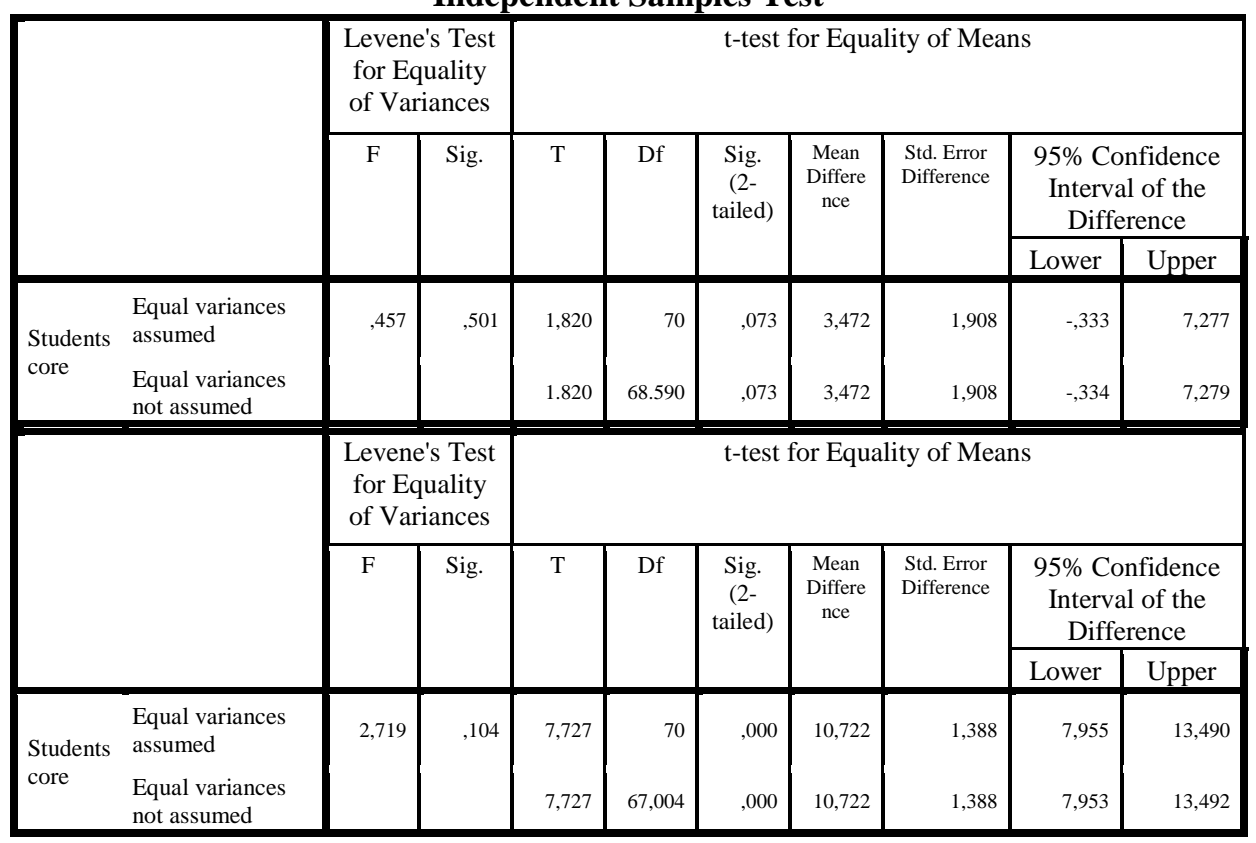

Based on the result of the data analysis as summarized in table 6 in the pre-test of the experimental and the control groups, the researcher found that the probability value or p-value (0.073) was higher than the level of significance $\alpha(0.05)$ or $0.073>0.05$. Whereas, the data in the posttest of the experimental group and control group shows that probability value (p-value) was smaller than $\alpha(0.000<0.05)$. It means that the alternative hypothesis (H1) is accepted while the null hypothesis is rejected. It assumed that there is a significant difference between the students' reading comprehension improvement in the experimental group and the control group after the treatment.

\section{Students' Interest}

In accordance with the findings, it shows that the first-grade students of SMAN 5 Makassar were interested in learning reading comprehension process by using Prezi and KWL Strategy. Most of the students' responses in the experimental group were categorized as 'interested'. 
28| ELT Worldwide Vol. 3 No. 1 April 2016

Table 8 The Percentage of Students' Interest

\begin{tabular}{|c|c|l|c|c|}
\hline No. & Interval & Categories & Frequency & Percentage (\%) \\
\hline 1 & $67-80$ & Very interested & 14 & 38.9 \\
2 & $54-66$ & Interested & 19 & 52.8 \\
3 & $42-53$ & Moderate & 3 & 8.3 \\
4 & $30-41$ & Uninterested & 0 & 0 \\
5 & $16-29$ & Very Uninterested & 0 & 0 \\
\hline \multicolumn{3}{|c|}{ Total } & 36 & 100 \\
\hline
\end{tabular}

According to the data of the students' interest classification, the students had the interest to learn English reading by using Prezi and KWL Strategy. It is proven by the mean score of the questionnaire which was 80.61 as classified into 'interested'. This also proven by the aggregate percentage of the students who got from the questionnaire on item 1 up 20 about items. The result (table 8) shows that $14(38.9 \%)$ students of 36 students were 'very interested', 19 $(52.8 \%)$ students of 36 students were 'interested', and $3(8.3 \%)$ students of 36 students were 'moderate'. from these findings, it can be inferred that most of the students have positive responses to the use of Prezi with KWL Strategy improving the students reading comprehension. In other words, the students are interested in reading a narrative text by using Prezi with KWL Strategy.

Furthermore, after analyzing between the result of the students' reading achievement and the students' interest in learning reading by using Prezi with KWL Strategy, it can be assumed that the use of Prezi with KWL Strategy is more applicable, effective and useful to increase the students' reading comprehension and the students' interest.

It is proven by the mean score of the experimental group in posttest which was 86.61 as categorized as very good classification while the mean score of interest was 80.61 as categorized as interested classification.

\section{CONCLUSION AND SUGGESTION}

The use of Prezi with KWL Strategy was effective to enhance the students' reading comprehension. This is proven by the mean score posttest of the students' in the experimental group and control group which were a difference. The mean score of the posttest in the experimental group was higher than the control group. 
Hamid, Rahman, Atmowardoyo: The Use of Prezi with Know ... 29

It can be seen from the students' mean score of post test was 86.61 for the experimental group, while for control group the students' mean score of post test was 75.89. Furthermore, the researcher found that all of the students' activities in using Prezi and KWL Strategy showed that the score of the students' in reading comprehension upgrades gradually.

The students' interest in the experimental group was interest to learn English reading by using Prezi with KWL Strategy. it was proven by the mean score of the questionnaire was 80.61 categorized as interested classification. Therefore, the researcher found that all of the indicators of interest were reached which could be seen on the students' involvement, feelings of pleasure, attraction and attention.

Based on the conclusion above, the researcher would put some suggestion and recommendation. In teaching reading especially in teaching reading narrative. The researcher should share to the other researchers to use Prezi as teaching media in learning English. The teaching learning process should collaborate the Prezi and KWL Strategy to enhance students' reading comprehension. Related to the previous suggestion, the next researchers are suggested to explore more on a blend of Prezi with another method, strategy, technique, or procedure that support teaching and learning the process. Consequently, Prezi and KWL Strategy not only enhancing the students' interest and reading comprehension but also helping improve the student's creative skills, independence, and recognize of using sophisticated of technology in learning besides, using a textbook as sources of learning. 
30| ELT Worldwide Vol. 3 No. 1 April 2016

\section{REFERENCES}

Depdiknas. 2006. Pembelajaran Bahasa Inggris. Jakarta: Badan Standar Nasional Pendidikan.

Gay, L.R., Millis, E., \& Airasian, P. 2006. Educational Research: Competencies for Analysis and Application. New Jersey. Prentice Hall.

Good.1959. The Dictionary of Education. New York: McGraw-Hill Book Company.

Hamra, A., \& Syatriana, E. 2010. Developing a Model of Teaching Reading Comprehension for EFL Students. TEFLIN Journal. 21(1): 27-40 retrieved from www.journal.teflin.org/index.php/journal/.../33 September, $18^{\text {th }} 2015$

Harmer, J. 1985. The Practice of English Language Teaching. United States of America: Longman

Hawa, S. N. 2013. The Effect of Using Know Want Learn (KWL) Plus Strategy toward Reading Comprehension on Exposition Text of the Second Grade Students at Islamic Senior High School AlKautsar Pekanbaru. Teaching Training Faculty of State Islamic University (UIN) Sultan Syarif Kasim Riau. Riau. Accessed on October, $21^{\text {st }} 2015$.

Jared, J., \& Elizabeth, J.H.A. 1997. Launching into Improved Comprehension. Technology The researcher, 56(6), 24-31

Manning, C., Brooks, W., Crotteau, V., Diedrich, A., Moser, J., \& Zwiefelhofer. 2011. Tech Tools for The researchers by The researchers: Bridging The researcher and Students. Wisconsin English Journal. 53(1): 24-28 retrieved from www. journals.library.wisc.edu/index.php/wej/.../444. October, $21^{\text {st }}$ 2015

Ogle, D.M. 1986. Teaching Reading Model that Develop Active Reading the Heading The researcher. Evanston: Illinois.

Pintrich, R.E., Romeo,G.C., \& Muller, S.A.B. 1999. Integrating Reading Strategies into the Accounting Curriculum. College Student Journal. 33(1): 77-82 
Hamid, Rahman, Atmowardoyo: The Use of Prezi with Know ... $\mid 31$

Riswanto., Risnawati., \& Lismayanti, D. 2014. The Effect of Using KWL (Know, Want, Learned) Strategy on EFL Students' Reading Comprehension Achievement. International Journal of Humanities and Social Science. 4 (7) : 225-231 retrieved from www.ijhssnet.com/journals/Vol_4.../28.pdf. October, $11^{\text {st }}$ 2015

Rivers, W. M. 1987. Teaching Reading Comprehension: An Interactive Pedagogy. New Jersey: San Fransisco State University.

Setiawan, A., Ikhsamuddin., \& Suhartono, L. 2013. The Effective of Teaching Reading Comprehension of Descriptive Text through KWL Strategy. The researcher Training Education Faculty of Tanjung University. Pontianak.

Strasser, N. 2014. Using Prezi In Higher Education. Journal of College Teaching \& Learning. 11 (2) : 95-98. Accessed on November, $4^{\text {th }} 2015$

Sugiyono. 2008. Metode Penelitian Pendekatan Kualitatif dan Kuantitatif, dan $R \& D$. Bandung: Alfabeta

William, E. 1984. Reading in the Language Classroom. London. McMilan.

Zare, P., \& Othman, M. 2013. The Relationship between Reading Comprehension and Reading Strategy Use among Malaysian ESL Learners. International Journal of Humanities and Social Science, 3 (13). Accessed on October, $9^{\text {th }} 2015$ 